\title{
First record of the rare bat Gardnerycteris koepckeae (Gardner \& Patton, 1972) (Chiroptera, Phyllostomidae) in Bolivia
}

\author{
Lizette Siles $^{1 *}$, Robert B. Wallace ${ }^{2}$ \\ 1 Museo de Historia Natural Alcide d'Orbigny, Av. Potosi 1458, Cochabamba, Bolivia \\ 2 Wildlife Conservation Society, Greater Madidi-Tambopata Landscape Conservation Program, Casilla 3-35181, San Miguel, La Paz, Bolivia \\ * Corresponding author: liz.siles@gmail.com
}

\begin{abstract}
The phyllostomid bat Gardnerycteris koepckeae (Gardner \& Patton, 1972) was considered endemic to Peru and restrict to only two localities, until it was recently collected in a new locality in Colombia. Now we report G. koepckeae for the first time in Bolivia, based on a specimen collected in a well-preserved montane forest inside the Parque Nacional y Área Natural de Manejo Integrado Madidi. The site of capture is at $2280 \mathrm{~m}$, which is the highest elevational record for the species. Gardnerycteris koepckeae is a rare species restricted to a fragile ecosystem threatened by mining and other changes in land use.
\end{abstract}

\section{Keywords}

Andes, Identidad Madidi, Koepcke's Hairy-nosed Bat, Madidi National Park, montane forest, Peru, Yungas

Academic editor: Marcelo Nogueira | Received 17 September 2020 | Accepted 3 December 2020 | Published 5 January 2021

Citation: Siles L, Wallace RB (2021) First record of the rare bat Gardnerycteris koepckeae (Gardner \& Patton, 1972) (Chiroptera, Phyllostomidae) in Bolivia. Check List 17 (1): 1-6. https://doi.org/10.15560/17.1.1

\section{Introduction}

The phyllostomid bat Gardnerycteris koepckeae (Gardner \& Patton, 1972) was originally placed in the genus Mimon Gray, 1847, subgenus Anthorhina Lydekker, 1891. This species was subsequently placed in a separate genus, Gardnerycteris Hurtado \& Pacheco, 2014, based on morphological data (Hurtado and Pacheco 2014) and supported by molecular analyses (Hurtado and D'Elía 2018). Soon after the species was described, Koopman (1976) considered it to be a junior synonym of Gardnerycteris crenulatum (É. Geoffroy, 1803) and later a highland subspecies (Koopman 1993). More recently, several researchers confirmed the validity of the species (e.g., Simmons 2005), and Hurtado et al. (2014) provided a detailed redescription. Currently, G. koepckeae is known from six specimens in total (Fig. 1), five of which were collected from two localities in Peru in 1970 (three specimens), 1971, and 2011 (Gardner and Patton 1972; Hurtado et al. 2014), and one specimen collected in 2012 in Colombia (Morales-Martínez et al. 2020). The known localities for G. koepckeae range in elevation from 1080 $\mathrm{m}$ in Colombia to $1900 \mathrm{~m}$ in Estera Ruana, Ayacucho Department, Peru (Hurtado et al. 2014; Morales-Martínez et al. 2020). Consequently, the species' distribution range is restricted to lower montane forests on the eastern slopes of the Peruvian Central Andes (Hurtado et al. 2014) and the Andean-Amazonian foothills in Colombia (Morales-Martínez et al. 2020). Peruvian legislation considers this species as Critically Endangered (Tello and Mena 2018); however, the IUCN Red List categorizes it as Data Deficient (Velazco and Aguirre 2019). Here we 


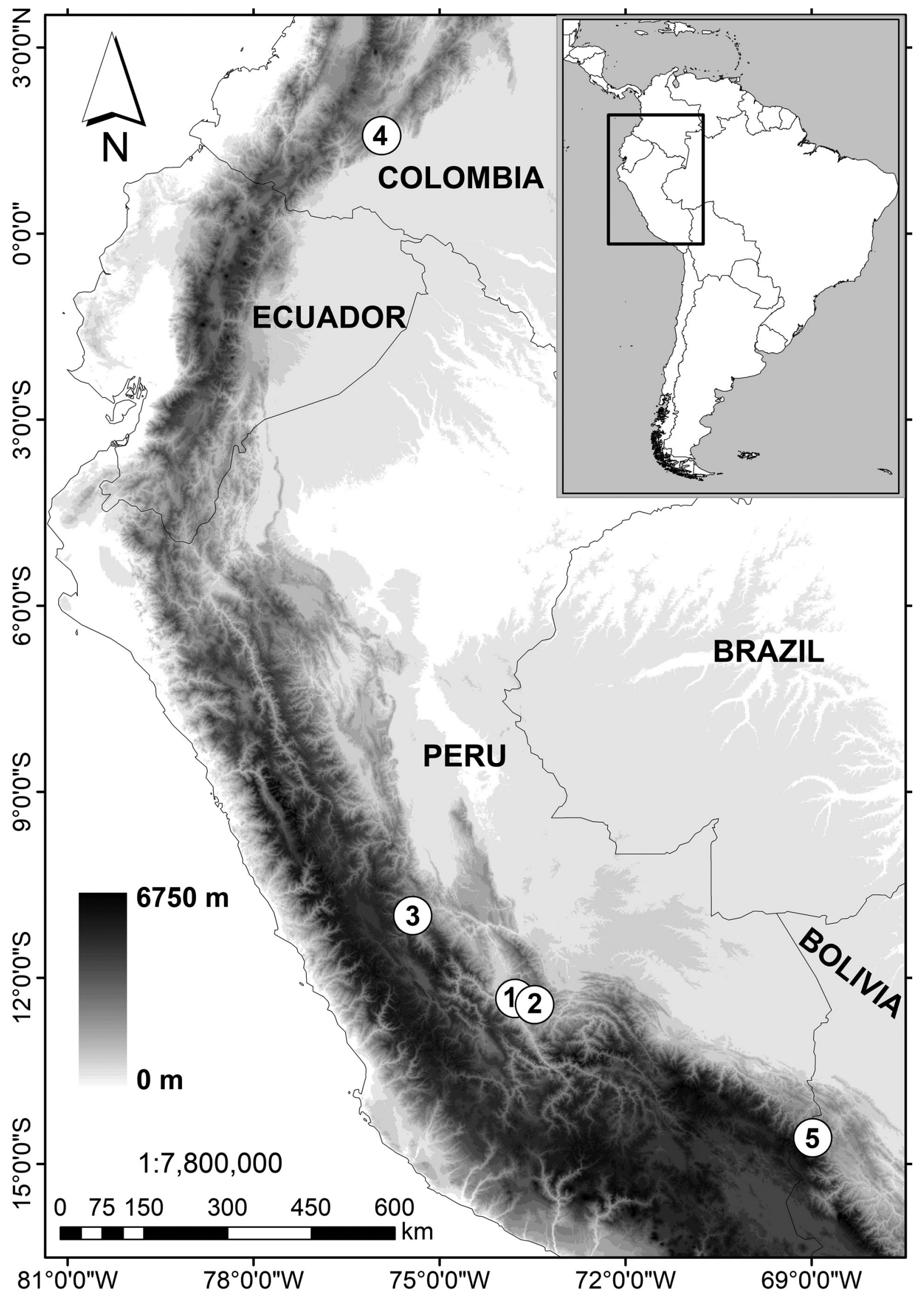

Figure 1. Map of collecting localities of Gardnerycteris koepckeae. 1. Huanhuachayo, Peru; $12.3333^{\circ} \mathrm{S}, 073.7833^{\circ} \mathrm{W}$; alt. ca $1660 \mathrm{~m}$; vouchers LSUMZ 16447 holotype and LSUMZ 15675 paratype. 2. Estera Ruana, Peru; $12.4333^{\circ} \mathrm{S}, 073.4667^{\circ} \mathrm{W}$; alt. $1900 \mathrm{~m}$; vouchers LSUMZ 15676 and AMNH 233222 topotype. 3. Podocarpus Santuario Nacional Pampa Hermosa, Peru; $10.9970^{\circ} \mathrm{S}, 075.4325^{\circ} \mathrm{W}$; alt. 1890 m; voucher MUSM 41327. 4. Belén de Los Andaquíes, Colombia; $01.5800^{\circ} \mathrm{N}, 075.9341^{\circ} \mathrm{W}$; alt. $1080 \mathrm{~m}$; voucher MHNUC 2010. 5. Cargadero PNANMI Madidi, Bolivia; $14.5780^{\circ} \mathrm{S}, 068.9801^{\circ} \mathrm{W}$; alt. $2280 \mathrm{~m}$; voucher CBF 8683 (this study). 
report a new record of this rare species captured during "Identidad Madidi", a three-year biodiversity project (2015-2017) in which we carried out faunal and floral surveys at 15 study sites across an altitudinal transect within the Parque Nacional y Área Natural de Manejo Integrado Madidi (PNANMI Madidi; in English, Madidi National Park and Natural Area of Integrated Management). We expected to find new distribution records for the park and Bolivia, especially for less studied groups, such as butterflies, plants, and small vertebrates. However, G. koepckeae was not in our list of expected bat species due to its rarity and apparent restriction to Peru when our project started (Hurtado et al. 2014).

\section{Methods}

As part of the Identidad Madidi initiative (http://www. identidadmadidi.org), we conducted biodiversity surveys from June 2015 to November 2017 at 15 localities throughout the PNANMI Madidi located in the Department of La Paz, Bolivia. The new record reported here was sampled in a montane forest of the Yungas ecoregion (according to Ibisch et al. 2003) between the Santa Rosa River and the Wayna sector. The site is well preserved, with a primary forest reached by foot after a 3-day hike. There are a few clearings due to historic human activity because decades ago, this area connected the Mojos and Apolo cantons (Wallace et al. 2019).

Understory mist-nets were used to capture bats for 10 nights (10 mist-nets of 6,9 , and $12 \mathrm{~m}$ placed $1 \mathrm{~m}$ from the ground), and the total effort employed in this site was $7453 \mathrm{~m}^{2} \cdot \mathrm{h}$ (calculated as mist-net area multiplied by the number of hours they were open). The specimen was collected following the guidelines by Sikes et al. (2016) and under the government research permit MMAYANMABCCGDF/DGBAP/UVSAP No. 354/2015. We extracted the skull, stored the specimen in alcohol, and deposited at the Colección Boliviana de Fauna (CBF) in La Paz, Bolivia.

Preliminary specimen identification was carried out in the field and later confirmed in the lab, with the cleaned skull, following the redescription of the species by Hurtado et al. (2014). We recorded length measurements, weight, age, and reproductive condition while in the field, and skull measurements in the lab. Forearm length and skull measurements were taken with digital calipers (Mitutoyo, Japan) to the nearest $0.01 \mathrm{~mm}$, following Lira et al. (1994) and Hurtado et al. (2014). Other body measurements were taken with a metallic ruler, and weight was taken with a spring scale (Pesola, Switzerland). Age was determined qualitatively by trans-illuminating the wing and observing the epiphyseal growth plate cartilage of the long phalanges of the fifth finger (Brunet-Rossinni and Wilkinson 2009).

The acronyms of scientific collections cited here are as follows: AMNH - American Museum of Natural History; CBF - Colección Boliviana de Fauna; LSUMZ Louisiana State University Museum of Natural Science;
MHNUC - Museo de Historia Natural Universidad del Cauca; and MUSM - Museo de Historia Natural Universidad Nacional Mayor de San Marcos. Specimen and locality information of other records of G. koepckeae was obtained from published literature and VertNet (http:// portal.vertnet.org), particularly to confirm the coordinates and elevation for Estera Ruana, Peru (Fig. 1). There are two coordinates reported for this locality in VertNet, one that was estimated for specimen LSUMZ 15676 and verbatim coordinates obtained from the catalogue scan of specimen AMNH 233222; we used the latter.

\section{Results}

New record. BOLIVIA • 1 đ adult; La Paz Department, Franz Tamayo Province, Parque Nacional y Área Natural de Manejo Integrado Madidi, Cargadero; $14^{\circ} 34.68^{\prime} \mathrm{S}$, 068 58.81'W; alt. ca 2280 m; 30 Sep. 2016; L. Siles leg.; montane forest; mist net; CBF 8683 (Fig. 2).

Identification. We identified the specimen in the field using the keys for South American phyllostomine species (Williams and Genoways 2008). In the lab, we corroborated the identification with the clean skull, and all diagnostic characters coincided: golden brown pelage color, absent dorsal stripe, crenulated noseleaf sparsely fringed with short fine hairs, small skull, narrow auditory bullae, first and second upper molars with narrow and well-defined vertical groove separating protocone and hypocone (Fig. 2). The only species it can be confused with is G. crenulatum because both have crenulated hairy noseleaf, forearm length shorter than 51 $\mathrm{mm}$, and skull length shorter than $25 \mathrm{~mm}$. However, $G$. crenulatum is differentiated by the presence of a dorsal stripe, longer palatal length, wider auditory bullae, and the absence of a vertical groove between the protocone and hypocone on the lingual cingulum of M1 and M2.

Furthermore, G. crenulatum is a lowland species (Hurtado et al. 2014; Solari 2019) and the specimen we collected from Cargadero was at an elevation of 2280 $\mathrm{m}$ (Fig. 1), which is the highest elevation reported for G. koepckeae to date. The external measurements of our specimen are within the range of G. koepckeae, except for ear length, which is slightly larger (Table 1). Cranial length measurements are also within the range, but several breadth measurements (postorbital, braincase, mastoid, M1-M1, and M2-M2) are slightly larger (Table 1), rendering a more robust form to the skull (Fig. 2). Diagnostic cranial measurements are the palatal length and auditory bulla breadth (Hurtado et al. 2014), and, in both cases, our specimen's measurements are within the range of G. koepckeae (Table 1).

Remarks. The specimen weighed $14 \mathrm{~g}$ and showed external testes; it was captured at 19:15 in an understory mistnet located near a small creek. The night of capture was cloudy, not windy, and light rain started to fall at approximately 22:00, which was expected weather because the survey was carried out during the transition between dry 


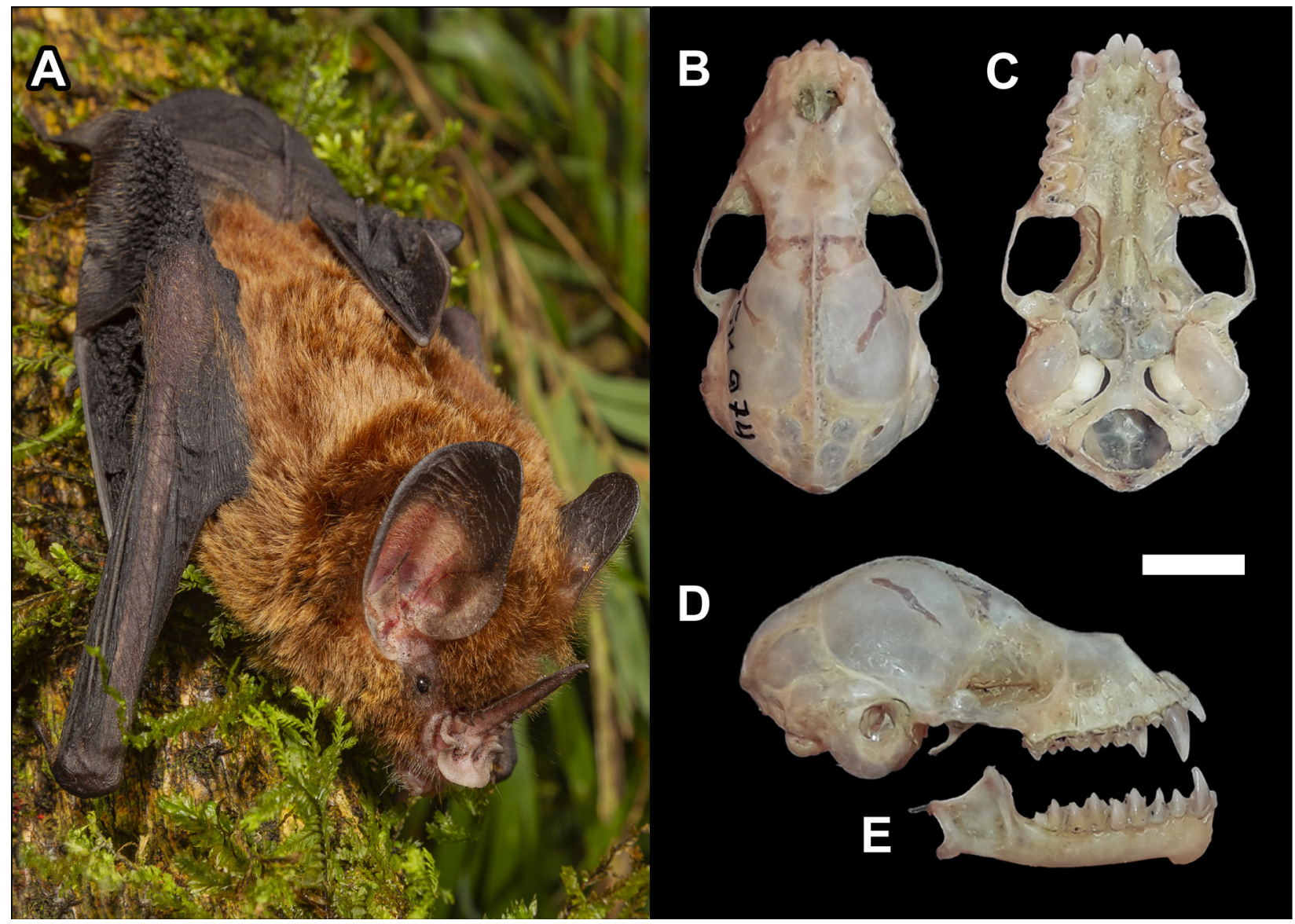

Figure 2. New Bolivian record of Gardnerycteris koepckeae CBF 8683. A. Live bat (photo credit Mileniusz Spanowicz SERNAP/WCS). B. Skull frontal view. C. Skull ventral view. D. Skull lateral view. E. Mandible. Scale bar $=5 \mathrm{~mm}$ for B-E. Photographs of skulls by LS.

Table 1. External and cranial measurements of Gardnerycteris koepckeae from Bolivia (this study) in comparison with Colombian (MoralesMartínez et al. 2020) and Peruvian (Hurtado et al. 2014) specimens, and data from a large series of G. crenulatum from Peru (Hurtado et al. 2014). Descriptive statistics for Peruvian specimens: mean \pm standard deviation (sample size). All measures are in millimeters.

\begin{tabular}{|c|c|c|c|c|}
\hline & \multicolumn{3}{|c|}{ Gardnerycteris koepckeae } & \multirow{2}{*}{$\begin{array}{c}\text { G. crenulatum } \\
\text { Peru }\end{array}$} \\
\hline & Bolivia & Colombia & Peru & \\
\hline Total length & 81 & 76.82 & $79.00 \pm 1.41(2)$ & $84.09 \pm 3.80(95)$ \\
\hline Tail length & 20 & 21.09 & $19.50 \pm 4.95(2)$ & $23.26 \pm 2.54(96)$ \\
\hline Hind foot length & 11 & 10.57 & $10.00 \pm 1.41(2)$ & $11.57 \pm 1.30(96)$ \\
\hline Ear length & 24 & 22.23 & $22.50 \pm 0.71(2)$ & $24.03 \pm 1.57(96)$ \\
\hline Forearm length & 49.96 & 48.09 & $47.70 \pm 0.42(2)$ & $48.02 \pm 3.39(96)$ \\
\hline Greatest length of skull & 21 & 20.83 & $21.11 \pm 0.74(3)$ & $21.50 \pm 0.68(92)$ \\
\hline Condyle-incisors length & 19.38 & 18.71 & $18.79 \pm 0.21(3)$ & $19.09 \pm 0.61(91)$ \\
\hline Postorbital breadth & 4.57 & 4.02 & $4.14 \pm 0.06(3)$ & $4.26 \pm 0.16(91)$ \\
\hline Zygomatic breadth & 11.87 & 11.25 & $11.67 \pm 0.24(3)$ & $12.13 \pm 0.46(90)$ \\
\hline Braincase breadth & 8.84 & 8.35 & $8.41 \pm 0.06(2)$ & $8.71 \pm 0.38(91)$ \\
\hline Mastoid breadth & 11.38 & 10.48 & $9.92 \pm 0.86(3)$ & $9.70 \pm 0.35(92)$ \\
\hline Palatal length & 8.44 & 7.62 & $8.44 \pm 0.33(3)$ & $9.70 \pm 0.40(92)$ \\
\hline Width at M1-M1 & 7.89 & 7.33 & $7.43 \pm 0.18(2)$ & $7.59 \pm 0.28(92)$ \\
\hline Width at M2-M2 & 8.55 & 8.17 & $8.04 \pm 0.19(3)$ & $8.26 \pm 0.30(92)$ \\
\hline Auditory bulla breadth & 2.19 & 2.30 & $2.36 \pm 0.19(2)$ & $2.75 \pm 0.14(91)$ \\
\hline Maxillary toothrow length & 7.86 & 7.80 & $7.71 \pm 0.36(3)$ & $7.88 \pm 0.23(92)$ \\
\hline Coronoid height & 4.23 & - & $4.46 \pm 0.17(2)$ & $4.39 \pm 0.25(91)$ \\
\hline Dentary length & 14.14 & - & $13.47 \pm 0.38(3)$ & $13.89 \pm 0.50(91)$ \\
\hline Mandibular toothrow length & 8.42 & - & $8.69 \pm 0.06(2)$ & $8.94 \pm 0.27(91)$ \\
\hline
\end{tabular}

and rainy seasons (Arteaga 2007). Other bats captured at the same locality during this survey were: Carollia brevicauda (Schinz, 1821), C. manu Pacheco, Solari, \& Velazco, 2004, Myotis keaysi J. A. Allen, 1914, M. nigricans (Schinz, 1821), Platyrrhinus masu Velazco, 2005, P. umbratus (Lyon, 1902), Sturnira erythromos (Tschudi, 1844), S. magna de la Torre, 1966, and S. oporaphilum (Tschudi, 1844). 


\section{Discussion}

In Bolivia, Gardnerycteris koepckeae can only be confused with $G$. crenulatum, which is considered a lowland species (Solari 2019). There are two sources of Bolivian published records for G. crenulatum (Anderson 1997; Terán 2010), but we found an error in Terán's (2010) data. Terán (2010) reported several individuals of G. crenulatum in La Paz, which included a photographic record by one of us (LS) from the locality Bajo Inicua. The latitude provided by Terán (2010) was not correct, leading to an overestimation of the elevation in this locality (1455 m). The accurate coordinates are $15^{\circ} 17^{\prime} 51^{\prime \prime} \mathrm{S}, 067^{\circ} 26^{\prime} 44^{\prime \prime} \mathrm{W}$, and the correct elevation is $330 \mathrm{~m}$. Therefore, G. crenulatum has an elevation range of $139-330 \mathrm{~m}$ in Bolivia (Anderson 1997; LS unpublished data 2007), confirmed with the elevation range of other specimens in museum collections. In Peru, the distribution for this species ranges from 300 to $900 \mathrm{~m}$ (Hurtado et al. 2014), while G. koepckeae occurs at a higher elevation (1080-2280 m; Morales-Martínez et al. 2020; this study). Therefore, the two species can be sympatric along the $1000 \mathrm{~m}$ line, at least in Peru.

Gardnerycteris koepckeae was described as a very rare species, endemic to Peru, known from the type locality, its surroundings in Ayacucho Department (alt. $1660 \mathrm{~m}$ ), and from a specimen collected in Junin Department (alt. 1890 m) 40 years later (Hurtado et al. 2014). More recently, an unexpected record from an adjacent habitat in Colombia, Department of Caquetá (alt. 1080 m) extended the distribution $1400 \mathrm{~km}$ further north (Morales-Martínez et al. 2020). The record in Bolivia expands the distribution of this species $558 \mathrm{~km}$ southsoutheast from the type locality (the closest point, Fig. 1), and the altitudinal limit from 1900 to $2280 \mathrm{~m}$. This remarkable and recent distribution extension opens the possibility of finding more records, particularly in northern Peru and Ecuador, as well in similar montane habitats in central Bolivia.

Furthermore, we observed morphological differences that may be worth exploring. For instance, the skull shape, particularly in the Bolivian specimen, is more robust in the postorbital region (Fig. 2B). As for the Colombian and Peruvian specimens, despite their similar skull, a cytochrome-b analysis yielded a 2.9\% divergence between these specimens using the Kimura 2-parameter model (Morales-Martínez et al. 2020). The authors use this value to confirm the identification because it is consistent with intraspecific variation for several phyllostomid species (Bradley and Baker 2001). However, based on more recent data, Velazco and Lim (2014) consider that values $\geq 2 \%$ do separate valid species in the family, and examples in the lower range can be found in Platyrrhinus Saussure, 1860 (Velazco and Patterson 2008), Micronycteris Gray, 1866 (Larsen et al. 2011), and Sturnira Gray, 1842 (Velazco and Patterson 2013). Although we were not able to sequence our specimen yet, when further data is gathered for G. koepckeae, it will be interesting to analyze genetic and morphological variations across its distribution.

Hurtado et al. (2014) argued that the few records reported for G. koepckeae might reflect the lack of sampling in montane forest, but we disagree because fieldwork carried out in Bolivia has not resulted in more specimens. Examples of bat surveys at the Yungas ecoregion in the last 15 years include: 1) short 5-night evaluations carried out by one of us at two localities at 900 and $2070 \mathrm{~m}$, with 13 and 8 phyllostomid species captured in each site, respectively (LS unpublished data, 2005-6); 2) a 4-month survey at approximately $1400 \mathrm{~m}$ with 17 phyllostomid species reported by Montaño-Centellas et al. (2015); 3) a 2-year project carried out between 1400 and $1650 \mathrm{~m}$ by Moya et al. (2008), which reported 20 phyllostomid species. Also, in Identidad Madidi we surveyed 3 additional Yungas sites at 1870, 1600, and $1160 \mathrm{~m}$ for a total of 23 nights, which yielded 6, 14, and 19 phyllostomid species, respectively (Wallace et al. 2017; Wallace et al. 2019; Wallace et al. 2020). Following the criteria outlined by $\mathrm{Yu}$ and Dobson (2000), due to its probable low population size (three specimens in three countries reported from 2011 to 2016), narrow habitat, and patchy distribution range, G. koepckeae can be considered rare. Therefore, we confirm the rarity of G. koepckeae, at least in Bolivia, with a distribution restricted to preserved low Andean montane forest, an extremely speciose and fragile ecosystem, threatened by climate change and human disturbance (Ibisch and Mérida 2003; Ministerio de Medio Ambiente y Agua 2009). All this information must be considered to update the Bolivian and regional conservation status of this species.

\section{Acknowledgements}

The Wildlife Conservation Society and the Gordon and Betty Moore Foundation financed the Identidad Madidi initiative. The National Protected Area Service of Bolivia (SERNAP) and Madidi National Park and Natural Area of Integrated Management (PNANMI Madidi) provided logistical support. The Plurinational State of Bolivia provided research and collecting permits. We thank local communities 3 de Mayo and Puina for their help and for providing field guides. We also thank the Identidad Madidi logistics team, who organized the fieldwork, as well as the bat team Marisol Hidalgo (MHN Alcide d'Orbigny) and Justiniano Flores (Puina). We thank Marcelo Nogueira, Natalí Hurtado, and Héctor Ramírez-Chaves for providing helpful comments that improved this manuscript.

\section{Authors' Contributions}

LS carried out the bat fieldwork, specimen identification, and specimen measurements. RBW designed the Identidad Madidi project, developed funding streams for the initiative, organized field trips, and applied for collecting and research permits. Both authors prepared and edited the manuscript. 


\section{References}

Anderson S (1997) Mammals of Bolivia: taxonomy and distribution. Bulletin of the American Museum of Natural History 231: 1-652.

Arteaga LF (2007) Fenología y producción de semillas de especies arbóreas maderables en un bosque húmedo montano de Bolivia (PN ANMI Cotapata). Revista Boliviana de Ecología y Conservación Ambiental 21: 57-68.

Bradley RD, Baker RJ (2001) A test of the genetic species concept: cytochrome-b sequences and mammals. Journal of Mammalogy 82 (4): 960-973. https://doi.org/10.1644/1545-1542(2001)082 $<0960$ :ATOTGS $>2.0 . \mathrm{CO} ; 2$

Brunet-Rossinni AK, Wilkinson GS (2009) Methods for age estimation and the study of senescence in bats. In: Kunz TH, Parsons S (Eds) Ecological and behavioral methods for the study of bats. 2nd edition. Johns Hopkins University Press, Baltimore, MD, USA, 315-325.

Gardner AL, Patton JL (1972) New species of Philander (Marsupialia: Didelphidae) and Mimon (Chiroptera: Phyllostomidae) from Peru. Occasional Papers of the Museum of Zoology, Louisiana State University 43: 1-12.

Hurtado N, D'Elía G (2018) Taxonomy of the genus Gardnerycteris (Chiroptera: Phyllostomidae). Acta Chiropterologica 20 (1): 99115. https://doi.org/10.3161/15081109ACC2018.20.1.007

Hurtado N, Pacheco V (2014) Análisis filogenético del género Mimon Gray, 1847 (Mammalia, Chiroptera, Phyllostomidae) con la descripción de un nuevo género. Therya 5 (3): 751-791. https://doi org/10.12933/therya-14-230

Hurtado N, Arias E, Pacheco V (2014) Redescription of Mimon koepckeae (Chiroptera: Phyllostomidae). Zoologia (Curitiba) 31 (4): 377-88. https://doi.org/10.1590/S1984-46702014000400009

Ibisch PL, Mérida G (Eds) (2003) Biodiversidad: La Riqueza de Bolivia. Editorial Fundación Amigos de la Naturaleza, Santa Cruz, Bolivia, 683 pp.

Ibisch PL, Beck SG, Gerkmann B, Carretero A (2003) Ecoregiones y ecosistemas. In: Ibisch PL, Mérida G (Eds) Biodiversidad: La Riqueza de Bolivia. Editorial Fundación Amigos de la Naturaleza, Santa Cruz, Bolivia, 47-88.

Koopman KF (1976) Zoogeography. In: Baker RJ, Jones JK, Carter DC (Eds) Biology of the New World family Phyllostomatidae. Part I. Texas Tech Press, Lubbock, TX, USA, 39-47.

Koopman KF (1993) Order Chiroptera. In: Wilson DE, Reeder DM (Eds) Mammal species of the world, a taxonomic and geographic reference. 2nd edition. Smithsonian Institution Press, Washington, DC, USA, 137-241.

Larsen PA, Siles L, Pedersen SC, Kwiecinski GG (2011) A new species of Micronycteris (Chiroptera: Phyllostomidae) from Saint Vincent, Lesser Antilles. Mammalian Biology 76 (6): 687-700. https://doi.org/10.1016/j.mambio.2011.01.006

Lira IE, Mudespacher C, García Guido B (1994) Theria diccionario de mamíferos. AGT Editors, SA, México, DF, Mexico, 167 pp.

Ministerio de Medio Ambiente y Agua (2009) Libro rojo de la fauna silvestre de vertebrados de Bolivia. Ministerio de Medio Ambiente y Agua, La Paz, Bolivia, 571 pp.

Morales-Martínez DM, Ramírez-Chaves HE, Colmenares-Pinzón JE, Gómez LG (2020) The Koepcke's spear-nosed bat, Gardnerycteris koepckeae (Gardner and Patton, 1972) (Chiroptera: Phyllostomidae), is not endemic to Peru: first record from the Amazon foothills of Colombia. Mammalia 84 (5): 439-447. https://doi. org/10.1515/mammalia-2019-0107

Montaño-Centellas F, Moya MI, Aguirre LF, Galeón R, Palabral O, Hurtado R, Galarza I, Tordoya J (2015) Community and species-level responses of phyllostomid bats to a disturbance gradient in the tropical Andes. Acta Oecologica 62: 10-17. https://doi. org/10.1016/j.actao.2014.11.002

Moya, MI, Montaño-Centellas F, Aguirre LF, Tordoya J, Martínez J,
Galarza MI (2008) Variación temporal de la quiropterofauna en un bosque de Yungas en Bolivia. Mastozoología Neotropical 15 (2): 349-357. http://www.redalyc.org/articulo.oa?id=45716284020

Sikes RS, the Animal Care and Use Committee of the American Society of Mammalogists. (2016) 2016 Guidelines of the American Society of Mammalogists for the use of wild mammals in research and education. Journal of Mammalogy 97 (3): 663-688. https://doi.org/10.1093/jmammal/gyw078

Simmons NB (2005) Order Chiroptera. In: Wilson DE, Reeder DM (Eds) Mammal species of the world: a taxonomic and geographic reference. 3rd edition. Johns Hopkins University Press, Baltimore, USA, 312-529.

Solari S (2019) Gardnerycteris crenulatum. The IUCN Red List of threatened species 2019: e.T13560A88177260. https://doi.org/ 10.2305/IUCN.UK.2019-1.RLTS.T13560A88177260.en. Accessed on: 2020-6-17.

Tello C, Mena JL (2018) Mimon koepckeae. In: Servicio Nacional Forestal y de Fauna Silvestre (Ed.) Libro Rojo de la fauna silvestre amenazada del Perú. Primera edición. GMC Digital SAC, Lima, Peru, 396.

Terán MF (2010) Nuevos registros de murciélagos (Chiroptera: Phyllostomidae: Phyllostominae) para el Departamento de La Paz, Bolivia. Revista Boliviana de Ecología y Conservación Ambiental 27: 85-91.

Velazco P, Aguirre LF (2019) Gardnerycteris koepckeae. The IUCN Red List of threatened species 2019: e.T136266A88183296. International Union for the Conservation of Nature. http://doi.org/ 10.2305/IUCN.UK.2019-1.RLTS.T136266A88183296.en. Accessed on: 2020-6-15.

Velazco PM, Lim BK (2014) A new species of broad-nosed bat Platyrrhinus Saussure, 1860 (Chiroptera: Phyllostomidae) from the Guianan Shield. Zootaxa 3796 (1): 175-193. http://doi.org/10.11646/ zootaxa.3796.1.9

Velazco PM, Patterson BD (2008) Phylogenetics and biogeography of the broad-nosed bats, genus Platyrrhinus (Chiroptera: Phyllostomidae). Molecular Phylogenetics and Evolution 49 (3): 749-759. https://doi.org/10.1016/j.ympev.2008.09.015

Velazco PM, Patterson BD (2013) Diversification of the yellow-shouldered bats, genus Sturnira (Chiroptera, Phyllostomidae), in the New World tropics. Molecular Phylogenetics and Evolution 68: 683-698. https://doi.org/10.1016/j.ympev.2013.04.016

Wallace R, Ramírez Yaksic A, Salinas E, Zenteno Ruiz F, Ayala G, Bernal Hoverud N, Siles L, Ocampo M, García VH, Miranda G, Molina J, Guerra Serrudo JF, SERNAP (2017) Informe de la expedición científica Identidad Madidi 2015. Relevamientos de biodiversidad en el Parque Nacional y Área Natural de Manejo Integrado Madidi. WCS-Bolivia, La Paz, Bolivia, 184 pp.

Wallace R, Ramírez Yaksic A, Salinas E, Zenteno Ruiz F, Ayala G, Bernal Hoverud N, Siles L, Ocampo M, García VH, Miranda G, Molina J, Guerra Serrudo JF, SERNAP (2019) Informe de la expedición científica Identidad Madidi 2016. Relevamientos de biodiversidad en el Parque Nacional y Área Natural de Manejo Integrado Madidi. WCS-Bolivia, La Paz, Bolivia, 200 pp.

Wallace R, Salinas E, Bernal Hoverud N, Zenteno Ruiz F, Ayala G, Siles L, Ocampo M, García VH, Miranda G, Molina J, Guerra Serrudo JF, Apaza M, Aparicio J, Ramírez Yaksic A, SERNAP (2020) Informe de la expedición científica Identidad Madidi 2017. Relevamientos de biodiversidad en el Parque Nacional y Área Natural de Manejo Integrado Madidi. WCS-Bolivia, La Paz, Bolivia, $227 \mathrm{pp}$.

Williams SL, Genoways HH (2008) Subfamily Phyllostominae Gray, 1825. In: Gardner AL (Ed.) Mammals of South America, volume 1: marsupials, xenarthrans, shrews, and bats. The University of Chicago Press, Chicago, USA, 255-299.

Yu J, Dobson FS (2000) Seven forms of rarity in mammals. Journal of Biogeography 27 (1): 131-139. 